\title{
Pengetahuan Persiapan Laktasi bagi Primigravida di Wilayah Puskesmas Tiron Kecamatan Banyakan Kabupaten Kediri
}

\author{
Aida Ratna Wijayanti ${ }^{1}$, Siti Komariyah ${ }^{2}$ \\ 1,2 Akademi Kebidanan Dharma Husada Kediri Jawa Timur \\ Email : ${ }^{1}$ aidaratna.Bd@ gmail.com Hp 081233677836 \\ 2 sitikomariyah.dh@gmail.com Hp 081334697967
}

\begin{abstract}
Abstrak
Persiapan Laktasi sangat diperlukan oleh ibu selama Antenatal Care terutama bagi Primigravida. Jika selama antenatal care tidak dipersiapkan dengan baik kemungkinan akan banyak timbul masalah mulai dari pengeluaran ASI yang tidak lancer sampai proses menyusui yang kurang tepat. Hal ini kemungkinan dikarenakan faktor ketidaktahuan ibu tentang proses laktasi terutama bebrapa posisi menyusui yang benar. Tujuan dari penelitian ini untuk mengetahui pengetahuan Persiapan laktasi bagi Primigravida di Wilayah Puskesmas Tiron Kecamatan Banyakan Kota Kediri. Desain Penelitian ini adalah deskriptif, pendekatan cross sectional. Populasinya semua ibu primigravida, dengan teknik total sampling didapatkan sampel sejumlah 30 responden. Variabel dalam penelitian ini merupakan variable tunggal yaitu pengetahuan persiapan Laktasi. Instrumen penelitian menggunakan kuesioner yang sudah di uji validitas dan realiabilitas. Pengolahan data meliputi coding, Editing, scoring, tabulating. Dianalisa dengan prosentase. Hasil penelitian menunjukkan dari 30 responden didapatkan 14 responden $(46,7 \%)$ berpengetahuan baik, 15 responden $(50 \%)$ berpengetahuan cukup, dan 1 responden $(3,3 \%)$ berpengetahuan kurang. Hasil penelitian mayoritas ibu primigravida memiliki pengetahuan yang cukup tentang persipan laktasi. Diharapkan ibu primigravida melalui kelas ibu hamil selama proses Antenatal Care akan lebih mengerti tentang persiapan laktasi dan dapat memberikan ASI Secara Ekslusif sampai usia 6 bulan. Dukungan dari Tenaga Kesehatan dan Lingkungan juga akan memberikan stimulus tersendiri terhadap ibu untuk mempersiapkan laktasi dengan baik selama kehamilan.
\end{abstract}

Kata kunci : Pengetahuan, Persiapan Laktasi, Primigravida

Korespondensi: RT 003/RW 003 Dsn Jeding, Kec. Junrejo, Kota Batu, Jawa Timur HP: 081233677836 ,email: aidaratna.Bd@gmail.com 


\section{Pendahuluan}

Laktasi adalah keseluruhan proses menyusui mulai dari ASI di produksi sampai proses bayi menghisap dan menelan ASI. Laktasi merupakan bagian dari siklus reproduksi manusia. Masa laktasi bertujuan meningkatkan ASI Ekslusif sampai usia 2 tahun dengan teknik yang baik dan benar (Kristiyansari, 2009).

Proses pembentukan air susu merupakan proses yang kompleks melibatkan hipotalamus, pituitary dan payudara, yang sudah dimulai saat fetus sampai pada masa pasca persalinan. ASI yang dihasilkan memiliki komponen yang yang konstan dan tidak sama dari waktu ke waktu tergantung stadium laktasi. Kehamilan pada wanita akan berdampak pada pertumbuhan payudara dan proses pembentukan air susu ibu ( Laktasi ). Proses ini timbul setelah ari - ari atau plasenta lepas. Plasenta mengandung hormone penghambat prolaktin (hormone plasenta) yang menghambat pembentukan ASI. Setelah plasenta lepas, hormone plasenta tersebut tak ada lagi, sehingga susu pun keluar (Asih, 2016)

Dengan teknik menyusui yang benar dapat meningkatkan produksi ASI.. WHO merekomendasikan pemberian ASI eksklusif dimulai dalam 1 jam setelah kelahiran bayi hingga usia 6 bulan. Dukungan dari keluarga, lingkungan, tenaga kesehatan dan Negara sangat dibutuhkan untuk keberhasilan pemberian ASI (Asih, 2016).

Terdapat berbagai macam posisi menyusui. Cara menyusui yang tergolong biasa dilakukan adalah dengan duduk berdiri atau berbaring. Kemudian cuci tangan yang bersih dengan sabun,perah sedikit dan oleskan sekitar puting. Bayi diletakkan menghadap ke ibu dengan posisi sanggah seluruh tubuh bayi,jangan hanya leher dan bayunya saja,kepala dan tubuh bayi lurus, hadapkan bayi ke dada sehingga hidung bayi berhadapan dengan puting susu,dekatkan badan bayi ke badan ibu, menyentuh bibir bayi ke puting susunya dan menunggu sampai mulut bayi terbuka lebar. Segera dekatkan bayi ke payudara sedemikian rupa hingga bibir bawah bayi terletak di bawah puting susu. Cara melekatkan mulut bayi dengan benar yaitu dagu menempel pada payudara ibu ,mulut bayi terbuka lebar dan bibir bawah bayi membuka lebar (Asih, 2016: 36)

Ibu-ibu sering kurang memahami tata laksana laktasi yang benar, misalnya bagaimana ASI keluar (fisiologi menyusui), bagaimana posisi menyusui dan perlekatan yang baik sehingga bayi dapat menghisap secara efektif dan ASI dapat keluar dengan optimal dengan teknik yang benar sehingga banyak susu keluar dari buah dada dan tidak menyebabkan puting susu lecet, atau menyebabkan bayi menelan udara terlalu banyak sehingga muntah, belum banyak diketahui oleh calon ibu dan tidak jarang bayi diberi susu formula karena ASI belum keluar pada hari pertama disangka ibu (Pratiwi, 2008).

Di Indonesia setiap 5 tahun sekali melakukan survey tentang menyusui. Menurut Survey Demografi dan Kesehatan Indonesia tahun 2013, di Indonesia persentase pemberian ASI saja dalam kurun waktu 2 tahun sebelum dilakukannya survey didapati hanya $27 \%$ bayi yang berumur 4-5 bulan mendapat ASI Eksklusif. Selain ASI, $8 \%$ bayi pada umur yang sama diberi susu lain dan $8 \%$ diberi air putih dikarenakan beberapa faktor (Kemenkes RI, 2013).

Teknik menyusui yang tidak benar dapat mengakibatkan puting susu menjadi lecet,ASI tidak keluar optimal sehingga mempengaruhi produksi ASI selanjutnya bayi enggan menyusu,untuk itu seorang ibu butuh seorang yang dapat merawat bayinya termasuk dalam menyusui. Ibu-ibu terlihat dapat menyusukan tetapi cara bagaimana menyusukan dengan teknik benar sehingga banyak susu keluar dari buah dada dan tidak menyebabkan puting susu lecet, atau menyebabkan bayi menelan udara terlalu banyak sehingga muntah, belum banyak diketahui oleh calon ibu (Ambarwati, 2008)

Berdasarkan studi pendahuluan yang dilakukan di BPM Ny. Istianah Di Desa Maron Kec. Maron Kab. Kediri di dapatkan dari hasil wawancara pada 8 primigravida, 5 primigravida masih menganggap bahwa ASI sama dengan susu formula, 2 primigravida tidak mampu menyusui bayinya karena ingin kembali bekerja setelah melahirkan, 1 primigravida primigravida ingin menyusui bayinya sampai usia 6 bulan.

\section{Metode}

Penelitian ini menggunakan rancangan penelitian deskriptif, dengan pendekatan penelitian cross sectioal. Populasi dalam penelitian ini adalah Semua ibu Primigravida di Wilayah Puskesmas Tiron Kecamatan Banyakan Kabupaten Kediri sebanyak 30 primigravida. Populasi sebagaimana tersebar di 9 Desa yaitu : 
Parang,Tiron, Jatirejo, Manyaran, Sendang, Banyakan, Jabon, Ngablak, Maron. Dengan teknik total sampling maka keseluruhan dari primigravida di wilayah tersebut dijadikan subjek penelitian. Alat Ukur yang digunakan dalam Hasil penelitian ini adalah kuesioner yang sudah diuji validitas dan reliabilitasnya. Etika dalam penelitian ini meliputi pemberian inform consent, anonimity, dan convidentiality.

\section{Karakteristik Responden}

\section{1) Karakteristik Responden Berdasarkan Umur}

\begin{tabular}{cllll}
\hline NO & Umur ( Tahun ) & Frekuensi & Prosentase $(\%)$ \\
\hline 1. & $<20$ & 5 & 16,7 \\
\hline 2. & $20-35$ & 25 & 83,3 \\
\hline 3. & $>35$ & & 0 & 0 \\
\hline & & Total & 30 & 100
\end{tabular}

Berdasarkan Tabel diatas dari 30 responden mayoritas primigravida berusia 20-35 tahun yaitu sejumlah 25 responden $(83,8 \%)$

\section{2) Karakteristik Responden Berdasarkan Pendidikan}

\begin{tabular}{llll}
\hline NO & Pendidikan & Frekuensi & Prosentase (\%) \\
\hline 1 & SD & 9 & 30 \\
\hline 2. & SMP & 10 & 30 \\
\hline 3. & SMA & 9 & 33,3 \\
\hline 4. & Perguruan Tinggi & 2 & 6,7 \\
\hline & Total & & 100
\end{tabular}

Berdasarkan Tabel dari 30 responden, $\quad$ sebagian besar responden berpendidikan SMP yaitu sebanyak 10 responden $(33,3 \%)$

\section{3) Karakteristik Responden Berdasarkan Pekerjaan}

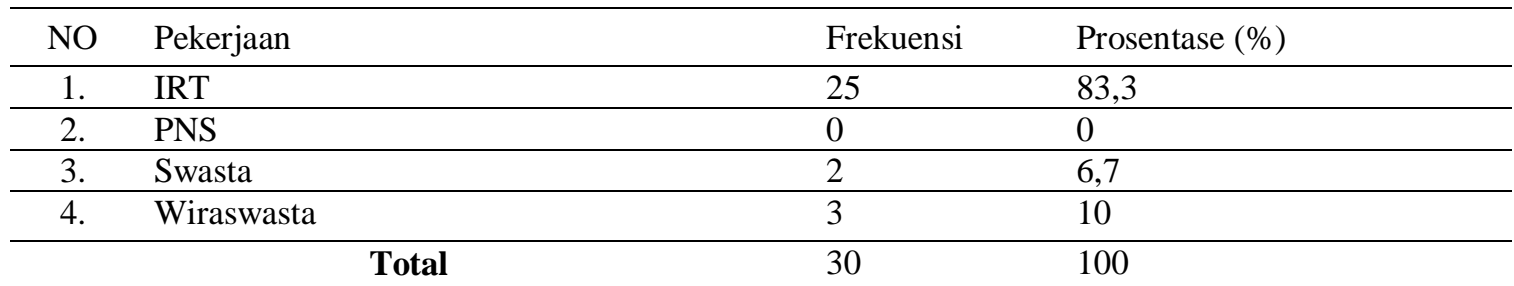

Berdasarkan Tabel tentang pekerjaan responden dari 30 responden, terdapat 25 responden $(83,3 \%)$ sebagai IRT.

\section{4) Karakteristik Responden Berdasarkan Sumber Informasi}

\begin{tabular}{clll}
\hline NO & Sumber Informasi & Frekuensi & Prosentase $(\%)$ \\
\hline 1. & Bidan/Petugas Kesahatan Lainnya & 9 & 56,25 \\
\hline 2. & $\begin{array}{l}\text { Media Masa (Televisi, Radio, Koran, } \\
\text { Majalah) }\end{array}$ & 2 & 12,5 \\
\hline 3. & Tetangga, Teman, Saudara) & 5 & 31,25 \\
\hline & Total & 16 & 100
\end{tabular}

Berdaaarkan tabel di atas terdapat 16 responden yang pernah mendapatkan informasi tentang persiapan laktasi (cara menyusui yang benar, sedangkan 14 responden belum pernah mendapatkan informasi) 


\section{Analisa Data Pengetahuan Persiapan Laktasi bagi Primigravida di Wilayah Puskesmas Tiron Kecamatan Banyakan Kabupaten Kediri}

\begin{tabular}{|c|c|c|c|c|c|c|c|c|c|}
\hline \multirow{3}{*}{ No } & \multirow{3}{*}{ Pengetahuan Ibu Primigravida } & \multicolumn{6}{|c|}{ Kriteria } & \multirow{2}{*}{\multicolumn{2}{|c|}{ Jumlah }} \\
\hline & & \multicolumn{2}{|c|}{ Baik } & \multicolumn{2}{|c|}{ Cukup } & \multicolumn{2}{|c|}{ Kurang } & & \\
\hline & & $F$ & $\%$ & $f$ & $\%$ & $f$ & $\%$ & $\sum$ & $\%$ \\
\hline 1 & Pengertian Laktasi & 25 & 83,3 & 4 & 13,3 & 1 & 3,3 & 30 & 100 \\
\hline 2 & Langkah Pemberian ASI & 2 & 6,7 & 18 & 60 & 10 & 33,3 & 30 & 100 \\
\hline 3 & Teknik Menyusui & 12 & 40 & 11 & 36,7 & 7 & 23,3 & 30 & 100 \\
\hline 4 & Posisi Menyusui & 12 & 40 & 10 & 33,3 & 8 & 26,7 & 30 & 100 \\
\hline 5 & Masalah Dalam Laktasi & 13 & 43,3 & 12 & 40 & 5 & 16,7 & 30 & 100 \\
\hline
\end{tabular}

Berdasarkan tabel di atas dari 30 responden sebanyak $25 \quad(83,3 \%)$ berpengetahuan baik tentang pengertian laktasi. Sedangkan untuk Langah pemberian ASI mayoritas respondne berpengetahuan cukup yaitu 18 (60\%). Untuk

\section{Diskusi}

1) Pengetahuan Ibu Primigravida tentang Pengertian Laktasi.

Berdasarkan data tentang Pengertian Laktasi dari 30 responden yaitu sebanyak 25 responden $(83,3 \%)$ berpengetahuan baik, 4 responden(13,3\%) berpengetahuan cukup, 1 responden $(3,3 ? \%)$ berpengetahuan kurang, dan bisa disimpulkan bahwa ibu primigravida mempunyai pengetahuan baik tentang pengertian laktasi.

Naluri seorang ibu terutama di kehamilan pertamanya tentunya ingin memebrikan yang terbaik bagi janinnya baiks elama kehamilan maupun setelah melahirkan terutama nutrisi 6 bulan pertama kelahiran.

Berdasarkan hasil penelitian menunjukkan bahwa pengetahuan ibu tentang pengertian laktasi masuk dalam kriteria baik. Ini dapat diketahui dari banyaknya responden yang menjawab dengan benar pada pertanyaan nomor 1 yaitu "Menyusui merupakan proses memberikan susu pada bayi/anak dari payudara ibu", didapatkan sebanyak 30 responden (100\%) menjawab benar. Pada pertanyaan no 3 juga dapat di kategorikan baik dilihat dari benarnya jawaban dari responden (100\%) yaitu " Kepanjangan dari ASI adalah air susu ibu, Dan juga pengetahuan ibu dapat di kategorikan baik di ketahui dari banyaknya responden yang menjawab dengan benar pada pertanyaan no 6 yaitu" Ada susu formula yang dapat menyamai ASI. Hal ini menunjukkan bahwa ternyata teknik menyusui dan posisi menyusui responden berpengetahuan baik sejumlah 12 responden (40\%), sedangkan pengetahuan mengenai masalah dalam laktasi berpengetahuan baik yaitu 13 responden $(43,3 \%)$.

responden telah mengetahui pengertian tentang menyusui dan ibu dapat dengan mudah menjawab soal pada kuesioner.

Selain itu pengetahuan responden juga dilatarbelakangi oleh pendidikan responden. Berdasarkan hasil penelitian diketahui bahwa 9 orang (30\%) Berpendidikan SD, 10 orang $(33,3 \%)$ Berpendidikan SMP, 9 orang $(30 \%)$ Berpendidikan SMA, dan 2 orang $(6,7 \%)$ Perguruan tinggi.

Pendidikan berarti bimbingan yang diberikan seseorang terhadap perkembangan orang lain yang menuju ke arah cita-cita tertentu yang menentukan manusia untuk berbuat dan mengisi kehidupan untuk mencapai keselamatan dan kebahagiaan. Pendidikan diperlukan untuk mendapat informasi misalnya hal-hal yang menunjang kesehatan sehingga dapat meningkatkan kualitass hidup. Menurut YB Mantra yang dikutup Notoadmojo (2003), pendidikan dapat mempengaruhi seseorang termasuk juga prilaku seseorang akan pola hidup terutama dalam memotivasiuntuk sikap berperan serta dalam pembangunan kesehatan.

Ibu primigravida yang berpendidikan SMP dan SMA/ menengah akan memiliki pengetahuan yang lebih baik dibandingkan dengan yang memiliki pendidikan rendah. Dengan dasar pendidikan yang dimiliki tersebut akan diketahui bahwa 16 orang $(53,3 \%)$ pernah mendapatkan informasi tentang cara menyusui yang benar dan 14 orang $(46,7 \%)$ belum pernah mendapatkan informasi. Selain itu didukung sebagian besar 
dari responden yaitu 9 orang (30\%) mendapat informasi dari tenaga kesehatan.

Informasi adalah sesuatu yang dapat diketahui, namun ada pula yang menekankan informasi sebagi tranfer pengetahuan. Selain itu informasi juga dapat didefinisikan sebagai suatu teknik untuk mengumpulkan, menyiapkan, menyimpan, memanipulasi, mengumumkan, menganalisis, dan menyebarkan informasi dengan tujuan tertentu (Budiaman 2014: 5).

Informasi tersebut dapat dijumpai dalam kehidupan sehari-hari, yang diperoleh dari data dan pengamatan terhadap dunia sekitar kita, serta diteruskan melalui komunikasi. Informasi mencakup data, teks, gambar, suara, kode, program komputer, dan basis data.

Pada penelitian responden memperoleh informasi terbanyak melalui petugas kesehatan meskipun hanya sebagian yang mendapatkan infomasi tersebut, kemudian sebagian lagi mendapatkan informasi dari media cetak dan elektronik. Dan sebagian kecil $46,7 \%$ belum pernah mendapat infomasi sama sekali tentang cara menyusui yang benar.

Ibu primigravida yang pernah mendapat informasi tentang cara menyusui yang benar akan mempunyai dasar pengetahuan dan wawasan yang baik. Dengan pengetahuan yang dimiliki oleh ibu primigravida tersebut akan menjadi dasar pengetahuan dan wawasan yang dimilikinya

Pada dasarnya semua ibu primigravida telah mendapatkan informasi tentang cara menyusui yang benar. Namun informasi tersebut ada yang dapat dicerna dengan baik dan ada yang tidak dapat dicerna dengan baik karena sebagian informasi yang mereka terima bersumber dari informasi yang salah (selain dari tenaga kesehatan secara langsung) sehingga menyebabkan timbulnya perbedaan pengetahuan antara ibu primigravida yang satu dengan yang lainnya

\section{2) Pengetahuan Ibu Primigravida tentang Langkah Pemberian ASI.}

Berdasarkan tabel tentang Langkah Pemberian ASI dari 30 responden yaitu sebanyak 2 responden $(6,7 \%)$ berpengetahuan baik, 18 responden $(60 \%)$ berpengetahuan cukup, 10 responden $(33,3 \%)$ berpengetahuan kurang, dapat disimpilkan bahwa pengetahuan ibu tentang langkah pemberian ASI yaitu cukup.
Langkah-langkah dalam pemberian ASI atau menyusui yaitu sebelum menyusui ASI dikeluarkan sedikit, bayi diletakkan menghadap perut ibu, payudara dipegang dengan ibu jari di atas dan jari yang lain menipang di bawah, bayi diberi rangsangan agar membuka mulut, kemudian setelah bayi membuka mulut dengan cepat kepala bayi didekatkan ke payudara ibu serta areola payudara dimasukkan ke mulut bayi, usahakan sebagian besar kalang payudara dapat masuk ke mulut bayi, sebagai putting susu berada dibawah langit-langit dan lidah bayi akan menekan ASI keluar dari tempat penampungan ASI yang terletak di bawah kalang payudara. Posisi salah, yaitu apabila bayi hanya menghisap pada pada putting saja, saja akan mengakibatkan masukan ASI yang tidak adekuat dan putting lecet dan setelah bayimulai menghisap payudara tak perlu di pegang atau disangga (Kristiyansari, $2009: 42$ ).

Kebanyakan ibu melupakan langkah langkah kecil sebelum proses menyusui dilakukan yang dapat membuat proses menyusui tidak maksimal.

Berdasarkan hasil penelitian menunjukkan bahwa pengetahuan ibu primigravida tentang langkah manyusui masuk dalam kriteria cukup. Ini dapat diketahui dari banyaknya jawaban salah pada pernyataan nomor 7 yaitu "Sebelum menyusui, ASI tidak perlu dikeluarkan terlebih dahulu", didapatkan hanya 8 responden $(33,3 \%)$ yang menjawab dengan benar. Berikutnya, pada soal nomor 8 yaitu "Pada saat menyusui bayi diletakkan menghadap dada ibu", didapatkan 0 responden $(0 \%)$ yang menjawab dengan benar. Selain itu hal ini juga diperkuat dari hasil penelitian pada soal nomor 12 yaitu "Agar memperoleh ASI secara maksimal, susukan bayi pada area puting susu saja" hanya 11 responden $(45,8 \%)$ yang menjawab dengan benar. Hal ini mempertegas bahwa pengetahuan ibu primigravida tentang langkah-langkah dalam menyusui masih kurang dan perlu ditingkatkan.

Pada umumnya ibu primigravida tidak pernah mengeluarkan ASI terlebih dahulu sebelum menyusui bayinya, padahal apabila ASI dikeluarkan terlebih dahulu sebelum menyusui, kemudian dioleskan pada puting dan sekitar kalang payudara banyak manfaat yang diperoleh salah satunya sebagai desinfektan dan menjaga kelembaban puting susu. Maka dari itu perlu dilakukan adanya penyuluhan dan mempraktekkan secara langsung pada ibu primigravida terkait langkah - langkah menyusui 
yang benar. Penyuluhan dan memberi contoh secara langsung dapat meningkatkan pengetahuan ibu, tapi tidak selalu dapat mengubah apa yang dilakukan oleh ibu. Banyak ibu yang mempunyai masalah, tapi tidak dapat mengemukakannya, atau bahkan masalahnya tidak dapat diselesaikan. Penting sekali bahwa kita sebagai petugas kesehatan berusaha agar ibu tertarik untuk menyusui.

\section{3) Pengetahuan Ibu Primigravida tentang Cara pengamatan Teknik Menyusui.}

Berdasarkan data tabel tentang Cara Pengamatan Teknik Menyusui dari 30 responden yaitu sebanyak 12 responden (40\%) berpengetahuan baik, 11 responden $(36,7 \%)$ berpengetahuan cukup dan 7 responden $(23,3 \%)$ berpengetahuan kurang, dapat disimpulkan bahwa pengetahuan ibu tentang cara pengamatan teknik menyusui baik.

Cara menyusu dengan teknik yang benar yaitu ciri-cirinya bayi tampak tenang, badan bayi menempel pada perut ibu, mulut bayi terbuka lebar, dagu bayi menempel pada payudara ibu, sebagian besar areola masuk ke dalam mulut bayi, areola bagian bawah lebih banyak yang masuk, bayi nampak menghisap kuat dengan irama perlahan, puting susu ibu tidak terasa nyeri, telinga dan lengan bayi terletak pada satu garis lurus, kepala agak menengadah, melepas isapan bayi setelah menyusu pada satu payudara sampai terasa kosong, sebaiknya ganti menyusui pada payudara lain. Menyusui berikutnya mulai dari payudara yang belum terkosongkan, setelah selesai menyusui ASI dikeluarkan sedikit kemudian dioleskan pada putting susu dan aerola sekitarnya, biarkan kering dengan sendirinya,dan jangan lupa untuk menyendawakan bayi (Suradi, :9).

Menyusui dengan teknik yang benar dapat mencegah puting susu menjadi lecet, ASI tidak keluar optimal sehingga mempengaruhi produksi ASI selanjutnya atau bayi enggan menyusu. Ibu memahami betul bagaimana ciri bayi yang sudah benar dalam menyusu. Saat bayi rewel dan merasa tidak nyaman pada saat proses menyusui, ibu akan segera tanggap mencari apa yang menjadi penyebab bayi tidak nyaman dalam menyusu.

Berdasarkan hasil penelitian menunujukkan bahwa pengetahuan ibu primigravida tentang cara pengamatan teknik menyusui masuk dalam kriteria baik. Ini dapat diketahui dari banyaknya jawaban benar pada pernyataan nomor 13 yaitu "Ciri teknik menyusui yang benar adalah bayi tampak tenang saat menyusu", didapatkan sebanyak 23 responden $(95,8 \%)$ dengan jawaban yang benar. Selanjutnya, pada soal nomor 16 yaitu "Menyusui dikatakan berhasil apabila sebagian besar areola (bagian yang bewarna hitam disekitar puting susu) masuk kedalam mulut bayi", didapatkan sebanyak 22 responden $(91,7 \%)$ dengan jawaban yang benar.

Pengetahuan dipengaruhi juga oleh faktor umur, berdasarkan tabel IV.1 dapat diketahui bahwa dari sejumlah 30 responden yang telah diteliti, prosentase tertinggi adalah berumur 2035 tahun yaitu sejumlah 25 responden $(83,3 \%)$.

Dengan bertambahnya umur seseorang akan mengalami perubahan aspek fisik dan psikologois mental. Secara garis besar, pertumbuhan fisik terdiri atas empat kategori perubahan yaitu perubahan ukuran, perubahan proporsi, hilangnya ciri-ciri lama, dan timbulnya ciri-ciri baru. Perubahan ini terjadi karena pematangan fungsi organ. Pada aspek psikologis atau mental, taraf berpikir seseorang menjadi semakin matang dan dewasa (Mubarak, 2011 : 83).

$\begin{array}{ccr}\text { Dengan demikian, umur } & \text { seseorang } \\ \text { mempengaruhi } & \text { pengetahuannya. }\end{array}$ dihubungkan dengan kematangan seseorang dalam berpikir. Semakin cukup umur, tingkat kematangan seseorang dalam berpikir akan lebih baik. Dengan tingkat kematangan yang cukup, seseorang mampu menangkap pengetahuan dengan baik sehingga dapat mengaplikasikan kedalam sikap yang baik pula.

Hal ini berarti penyuluhan kesehatan dalam promosi kesehatan diperlukan sebagai upaya meningkatkan penegtahuan dan kesadaran, disamping sikap dan perbuatan.

Selanjutnya diharapkan dapat tercapainya tujuan penyuluhan kesehatan yang lebih luas yaitu untuk merubah perilaku kesehatan menjadi lebih baik. Perilaku kesehatan sendiri meliputi perilaku dalam pemeliharaan kesehatan yaitu usaha - usaha seseorang untuk memelihara atau menjaga kesehatan agar tidak sakit dan usaha penyembuhan baik sakit. Perilaku pencarian dan penggunaan sistem atau fasilitas pelayanan kesehatan yaitu upaya atau tindakan seseorang pada saat menderita penyakit. Perilaku kesehatan lingkungan ialah bagaimana seseorang merespon lingkungan baik lingkungan fisik maupun sosial 
budaya sehingga lingkungan tersebut tidak mempengaruhi kesehatannya ( Notoatmodjo, 2007: 136).

Apabila tujuan penyuluhan diatas dapat dicapai, maka jalan untuk mencapai tujuan dari pemerintah dalam bidang kesehatan semakin dekat yaitu meningkatkan derajat kesehatan masyarakat, dalam penelitian ini adalah kesehatan wanita usia subur.

\section{4) Pengetahuan Ibu Primigravida tentang Posisi Menyusui}

Berdasarkan data dari tabel IV.6 tentang Posisi Menyusui dari 30 responden yaitu sebanyak 12 responden (40\%) berpengetahuan baik, 10 responden $(33,3 \%)$ berpengetahuan cukup, 8 responden berpengetahuan kurang, dan dapat dilihat bahwa pengetahuan ibu tentang posisi menyusui yaitu baik.

Posisi Menyusui ada 8 yaitu posisi menyusui berbaring miring, posisi menyusui duduk, posisi menyusui rebahan, posisi menyusui berdiri, posisi menyusui menggendong, posisi menyusui menggendong menyilang, posisi menyusui mengepit (football), posisi menyusui dengan kondisi khusus (Wiji, 2013 : 40).

Kebanyakan ibu memilih posisi yang nyaman bagi diri sendiri dan bayinya. Ibu lebih memilih posisi yang sederhana seperti posisi duduk, berbaring miring, dan menggendong. Hal ini sangat baik dikarenakan posisi yang nyaman dapat mempengaruhi keberhasilan pemberian ASI.

Berdasarkan hasil penelitian menunjukkan bahwa pengetahuan ibu tentang posisi menyusui masuk dalum kriteria baik. Ini dapat diketahui dari banyaknya jawaban benar pada soal nomor 20 yaitu "Posisi menyusui dengan duduk dapat dilakukan dengan posisi santai dan tegak dengan menggunakan kursi yang rendah agar kaki ibu tidak menggantung dan punggung ibu bersandar pada sandaran kursi", didapatkan sebanyak 23 responden $(95,8 \%)$ menjawab dengan benar. Kemudian pada soal nomor 21 yaitu "Pada saat posisi menyusui dengan berdiri, sebaiknya bayi tetap disangga dengan lengan ibu agar bayi merasa tenang dan tidak terputus saat menyusu", didapatkan 22 responden $(91,6 \%)$ menjawab dengan benar. Hal ini menunjukkan bahwa ibu memahami pengertian-pengertian dari posisi menyusui itu sendiri.

Pengetahuan ibu primigravida tentang cara menyusui yang benar dapat dipengaruhi oleh faktor pendidikan. Berdasarkan hasil data dari tabel IV.2 prosentase tertinggi adalah responden dengan tingkat pendidikan SMA yaitu sejumlah 10 responden $(33,3 \%)$.

Pendidikan berarti bimbingan yang diberikan seseorang terhadap perkembangan orang lain menuju kearah cita-cita tertentu yang menentukan manusia untuk berbuat dan mengisi kehidupan untuk mencapaikeselamatan dan kebahagiaan (Mubarak, 2011 : 83).

Ibu primigravida pasti sudah mempunyai pengetahuan mengenai cara menyusui yang benar. Tetapi ibu yang memiliki pengetahuan belum tentu memahami apa yang diketahuinya tersebut. Sehingga pemahaman sangat dibutuhkan untuk membuktikan seberapa besar pengetahuan yang diperoleh ibu tentang cara menyusui yang benar.

Untuk memahami suatu hal yang baru, tergantung dari kesiapan individu untuk menerima informasi tersebut. Pesan dan sugesti yang dibawa oleh suatu informasi apabila cukup kuat akan memberi dasar yang efektif dalam menilai sesuatu hal sehingga terbentuk pemahaman yang kuat dari pengetahuan yang sudah ada sebelumnya.

Tingkat pendidikan yang tinggi akan memudahkan responden dalam mengerti dan memahami apa yang diketahuinya setelah mendapatkan informasi. Jadi semakin tinggi pendidikan seeorang maka akan lebih mudah mengerti dan memahami hal-hal yang baru diketahuinya. Sebaliknya apabila tingkat pendidikannya rendah akan sedikit sulit untuk mengerti dan memahami hal-hal yang baru di sekitarnya. Tujuan dari pendidikan itu sendiri adalah dapat menciptakan sumber daya manusia yang berkualitas dan berkarakter sehingga memiliki pandangan yang luas untuk mengembangkan apa yang diketahuinya.

\section{5) Pengetahuan Ibu Primigravida Tentang Masalah Dalam Laktasi}

Berdasarkan data dari tabel IV.6 tentang Masalah Dalam Menyusui dari 30 responden yaitu sebanyak 13 responden $(43,3 \%)$ berpengetahuan baik, 12 responden $(40 \%)$ berpengetahuan cukup, 5 responden $(16,7 \%)$ berpengetahuan kurang,dapat disimpulkan bahwa pengetahuan ibu tentang masalah dalam menyusui yaitu baik.

Masalah yang terdapat dalam menyusui antara lain kurang atau salah informasi, puting susu datar atau terbenam, puting susu nyeri, 
puting susu lecet, Payudara bengkak, Mastitis atau abses payudara, masalah menyusui pada bayi yang meliputi: Bayi sering menangis, Bayi bingung puting, Bayi prematur, Bayi kuning, Bayi kembar, Bayi sakit, Bayi sumbing, Bayi dengan lidah pendek, Bayi yang memerlukan perawatan (Kristiyansari, 51).

Sebagian ibu menyadari masalah-masalah yang sering timbul pada proses menyusui misalnya puting susu terasa nyeri, puting susu lecet, maupun payudara bengkak. Hal ini disebabkan oleh beberapa faktor salah satunya yaitu kurangnya pengetahuan ibu dalam penanganan masalah-masalah tersebut. Ibu biasanya masih mengabaikan hal-hal kecil seperti membiarkan masalah - masalah menyusui yang terjadi karena menurut pengalaman mereka hal hal tersebut akan teratasi dengan sendirinya dan ibu tetap menyusui bayinya.

Umumnya menyusui akan menyakitkan dan kadang-kadang mengeluarkan darah. Puting susu lecet dapat disebabkan oleh posisi yang salah, tapi dapat pula disebabkan oleh thrush (candidates) atau dermatitis. Pada hari-hari pertama (sekitar 2-4 jam), payudara sering terasa penuh dan nyeri disebabkan bertambahnya aliran darah ke payudara bersamaaan dengan ASI mulai diproduksi dalam jumlah banyak.

Berdasarkan hasil penelitian menggambarkan bahwa pengetahuan ibu primigravida tentang masalah dalam menyusui masuk dalam kriteria baik. Ini dapat diketahui dari banyaknya jawaban benar pada soal nomor 30 yaitu "Apabila bayi sakit, ASI harus tetap

\section{Simpulan}

Dari hasil penelitian ini dapat disimpulkan bahwa mayoritas ibu primigravida berpengetahuan cukup tentang persiapan laktasi, untuk meningkatkan pengetahuan ibu diharapkan adanya peran aktif dari tenaga kesehatan untuk memberikan pendampingan terutama pada waktu kelas ibu hamil untuk memotivasi pelaksanaan laktasi.

\section{Daftar Pustaka}

Arikunto, Suharsimi. (2010). Prosedur Penelitian suatu Pendekatan Praktek. Jakarta : Rineka Cipta diberikan", didapatkan 30 responden $(100 \%)$ menjawab dengan benar.

Pengetahuan dapat dipengaruhi juga oleh faktor pekerjaan. Berdasarkan tabel IV.3 dapat diketahui bahwa dari 30 responden yang telah diteliti prosentase tertinggi pekerjaan responden adalah IRT (Ibu Rumah Tangga) yaitu sejumlah 24 responden $(80 \%)$.

Menurut Thomas yang dikutip oleh Nursalam, pekerjaan adalah keburukan yang harus dilakukan terutama untuk menunjang kehidupannya dan kehidupan keluarga. Pekerjaan bukanlah sumber kesenangan, tetapi lebih banyak merupakan cara mencari nafkah yang membosankan, berulang dan banyak tantangan. Sedangkan bekerja umumnya merupakan kegiatan yang menyita waktu. Bekerja bagi ibuibu akan mempunyai pengaruh terhadap kehidupan keluarga (Wawan, 2010 : 17).

Pekerjaan sangat berpengaruh pada keluarga terutama pada ibu dan bayinya. Pada ibu rumah tangga keuntungannya yaitu ibu dapat terusmenerus berlatih mengembangkan pengetahuannya di rumah karena ibu memiliki banyak waktu luang. Sehingga memungkinkan untuk mempraktikkan pengetahuan dan pemahamannya sesering mungkin tanpa dituntut dengan masalah pekerjaan. Jadi wajar apabila antara pengetahuan dan pemahaman ibu rumah tangga dengan wiraswasta maupun PNS (Pegawai Negeri Sipil) sangat berbeda. Pengetahuan yang baik ini perlu dipertahankan agar ibu dan bayinya mendapatkan manfaat dan hasil yang maksimal saat menyusui
(2013). Prosedur Penelitian suatu Pendekatan Praktek. Jakarta : Rineka Cipta

Budiman, Agus Riyanto., (2014). Kapita Selekta Kuesioner Pengetahuan Dan Sikap Dalam Penelitian Kesehatan. Jakarta: Salemba Medika.

Hidayat, A. Aziz. (2010). Metode Penelitian Kebidanan Teknik Analisis Data. Jakarta : Salemba Medika

. (2013). Metode Penelitian Kebidanan Teknik Analisis Data. Jakarta : Salemba Medika 
Kristiyansari, Weni. (2009). ASI,MENYUSUI \& SADARI. Yogyakarta : Nuha Medika

Ariani, Ayu Putri. (2014). Metodologi Penelitian Kebidanan dan Kesehatan Reproduksi. Jogjakarta : Nuha Medika

Nursalam. (2013). Metodelogi Penelitian Ilmu Keperawatan. Jakarta : Salemba Medika. . (2014). Metodelogi Penelitian Ilmu Keperawatan. Jakarta : Salemba Medika.

Saleha, Siti. (2009). Asuhan Kebidanan Pada Masa Nifas. Jakarta : Salemba Medika

Sugiyono. (2011). Metode Penelitian Kuantitatif Kualitatif dan $R \& G$. Bandung : CV Alfabeta
(2012). Metode Penelitian Kuantitatif Kualitatif dan $R \& G$. Bandung : CV Alfabeta

Sujarweni. (2014). Metode Penelitian. Yogyakarta : Pustaka Baru Pres

Suradi, Rulina. Manajemen Laktasi. Jakarta : Perinasia

Wawan \& Dewi. (2010). Pengetahuan, Sikap, dan Perilaku manusia. Yogyakarta : Nuha Medika

Wiji, Rizki Natia. (2013). ASI dan Panduan Ibu Menyusui. Yogyakarta : Nuha Medika 